ISSN 0258 - 7122

Bangladesh J. Agril. Res. 32(3) : 433-444, September 2007

\title{
FACTORS AFFECTING PROFITABILITY OF SUGARCANE PRODUCTION AS MONOCULTURE AND AS INTERCROP IN SELECTED AREAS OF BANGLADESH
}

\author{
M. KamRuzzaman ${ }^{1}$ And M. Hasanuzzaman ${ }^{2}$
}

\begin{abstract}
The study was undertaken to know the profitability of sugarcane production as monoculture and as intercrop. Data were collected from 70 sugarcane growers of Daulatpur Upazilla under Kushtia District. Data were collected during the period from February to July 2003. The study reveals that the sugarcane plus potato combination produced the highest net return followed by sugarcane plus maize, sugarcane plus lentil and sole sugarcane production. Family labour cost, cost of urea, number of fertilizing, sowning/planting time of intercrop, cost of sett were the important factors which influence the profitability of sugarcane production both as intercrop and as nonoculture. High prices of inputs, lack of scientific knowledge, and dishonesty of officials are the major problems in sugarcane production. In order to promote intercropping in a large scale with sugarcane, government and other related organizations must encourage farmers to produce sugarcane as intercrop in order to earn higher net return.
\end{abstract}

Key Words: Profitability of sugarcane, monoculture, intercrop.

\section{Introduction}

The total cropped area of Bangladesh is estimated to be 35267 hectares with cropping intensity of 175 percent (BBS, 2002). Sugarcane is the second most important cash crop, which is grown in almost all districts of Bangladesh. It concentrates mainly in the greater districts of Rajshali, Kushtia, Jessore, Rangpur, Dinajpur, Bogra, Pabna, Faridpur, Barisal, Dhaka, and Mymensingh.

There is a little scope of horizontal expansion of land for increasing production. The only way for farmers to increase their farm income is to make intensive use of land. Sugarcane is a long duration crop, which occupies the land for 10-14 months from planting to harvesting. Small and medium farmers, who are mainly sharecroppers in Bangladesh, cannot afford to wait for such a long period due to poor financial conditions as well as higher demand for food and vegetables for their family members. As a result, they tend to reduce cane cultivation and increase other corps (Miah, 1992). During the long period, the poor famers practiced intercropping with sugarcane in order to raise overall crop productivity and to increase their income. One of the most important

${ }^{1}$ Asstt. Professor, Deptt. of Agricultural Economics, BSMRAU Gazipur-1706, ${ }^{2} \mathrm{MS}$ Student, Deptt. of Agricultural Economics, BSMRAU, Gazipur-1706, Bangladesh. 
considerations to use intercropping with sugarcane was to produce an additional crop with minimum investment without affecting the overall production of the main crop.

If intercropping can be introduced with sugarcane, the overall productivity and incomes will increase. In that case farmers may be interested to produce an additional crop with minimum investment. This may be helpful for farmers to go for increased production. This study further emphasizes that it would be possible to identify the best intercropping systems and possible solution of farmer's problems. This study will also be very much helpful for researchers, policy makers, and planners. It provides valuable information to the government and related agencies for wide scale adoption of intercropping. This study also expected to assist planners in making effective and judicious plan in respect of production, consumption, and formulation of macro and micro policies for agricultural development. The specific objectives of the study are: (1) to compare the profitability of sugarcane as monoculture and intercrop with crops under crop diversification programme (2) to identify the factors influencing the profitability of sugarcane production as monoculture and intercropping of various crops under crop diversification programme.

A little effort was made to study on the economics of sugarcane production and its intercrop by different research organizations and institutions. A few economic studies on sugarcane and its intercrop were also conducted in India. Gana and Busari (1999) conducted a study to evaluate the yield and returns of sugarcane intercropping with horticultural crops in the Southern Guinea Savanna of Nigeria in 1997 and 1998. Chujaemi et al. (1998), Singh and Chauhan (1998), Zohry (1999), Gangwar and Sharma (1997), Muhammad et al. (1998) and Shankaraiah et al. (1999) conducted a field experiment on sugarcane intercropping. Imran et al. (2000) conducted an experiment on intercropping systems for sugarcane at Saro Shah Research and Seed Multiplication Farm of the Premier Sugar Mills during 1994-95 and 1995-96. Sarjit et al. (1999) conducted a field study in 1994-97 at Jalandhar, India and found that sugarcane was grown alone or intercroped with cabbage (1:1), lentils (1:2), linseed (1:2) or fodder oats (1:2). Miah (1992) studied on profitability of sugarcane production as intercrop but comparative profitability of sugarcane as monoculture and intercrop for the crops under crop diversification programme is not yet studied.

\section{Methodology Selection of the study area, sampling techniques and samples}

Eighteen villages of Daulatpur Thana of Kushtia District were selected purposively. Finally, 70 growers were selected from the list of sugarcane growers by random sampling technique. Out of 70 samples, 40 were intercrop and 30 were sole sugarcane growers. To compare sole sugarcane, sugarcane plus lentil, sugarcane plus maize, sugarcane plus potato, and sugarcane plus others 
intercropping system were selected for this study (other intercrops include wheat, sunflower, and onion). Data were collected from February to July 2003.

\section{Analytical technique Cobb-Douglas production function}

To determine the effects of variable inputs, Cobb-Douglas production function was estimated. This functional form of regression model used in this study was as follows for sole sugarcane production.

$$
\begin{gathered}
\operatorname{InY}=\beta_{0}+\beta_{1} \ln X_{1}+\beta_{2} \ln X_{2}+\beta_{3} \ln X_{3}+\beta_{4} \ln X_{4}+\beta_{5} \ln X_{5}+\beta_{6} \ln X_{6}+\beta_{7} \ln X_{7}+ \\
\beta_{8} \ln X_{8}+\beta_{9} X_{9}+\beta_{10} X_{10}+\beta_{11} X_{11}+\beta_{12} X_{12}+\beta_{13} X_{13}+\beta_{14} \ln X_{14}+U i
\end{gathered}
$$

Where, In = Natural logarithm, $Y=$ Net return/ha Taka, $\beta_{0}=$ Intercept, $X_{1}=$ Cost of sets (Tk./ha), $X_{2}=$ Cost of total hired labour (Tk./ha), $X_{3}=$ Cost of total family labour (Tk./ha), $\mathrm{X}_{4}=$ Cost of urea (Tk./ha), $\mathrm{X}_{5}=$ Cost of TSP (Tk./ha), $\mathrm{X}_{6}$ $=$ Cost of MP (Tk./ha), $\mathrm{X}_{7}=$ Cost of insecticides (Tk./ha), $\mathrm{X}_{8}=$ Cost of irrigation (Tk./ha), $\mathrm{X}_{9}=$ Time of set transplantation (October-November is 1 and 0 otherwise), $X_{10}=$ Row to row distance $(\mathrm{cm}), X_{11}=$ Plant to plant distance $(\mathrm{cm})$, $X_{12}=$ Number of fertilizing. $X_{13}=$ Number of weedings, $X_{14}=$ Rent of land (Tk./ha), $U_{i}=$ Stochastic disturbance term, $\beta_{1}$--------- $\beta_{14}=$ Coefficients of respective variable.

The functional form of regression model used for intercropping system is as follows:

$$
\begin{aligned}
& \operatorname{InY}=\beta_{0}+\beta_{1} \ln X_{1}+\beta_{2} \ln X_{2}+\beta_{3} \ln X_{3}+\beta_{4} \ln X_{4}+\beta_{5} \ln X_{5}+\beta_{6} \ln X_{6}+\beta_{7} \ln X_{7}+ \\
& \beta_{8} \ln X_{8}+\beta_{9} X_{9}+\beta_{10} \ln X_{10}+\beta_{11} \ln X_{11}+\beta_{12} \ln X_{12}+U i
\end{aligned}
$$

Where, $Y=$ Net return/ha (Tk.), $X_{1}=$ Cost of sets (Tk./ha), $X_{2}=$ Cost of seed (Tk./ha), $\mathrm{X}_{3}=$ Cost of labour (Tk./ha), $\mathrm{X}_{4}=$ Cost of urea (Tk./ha), $\mathrm{X}_{5}=$ Cost of insecticides (Tk./ha), $X_{6}=$ Cost of irrigation (Tk./ha), $X_{7}=$ Cost of ploughing (Tk./ha), $\mathrm{X}_{8}=$ Rent of land (Tk./ha), $\mathrm{X}_{9}=$ Time of set transplantation as dummy (October-November is 1 and 0 therwise), $\mathrm{X}_{10}=$ Sowing time of intercrop as dummy (October-November is 1 and 0 otherwise), $X_{11}=$ Row to row distance $(\mathrm{cm}), \mathrm{X}_{12}=$ Plant to plant distance $(\mathrm{cm})$.

\section{Results and Discussion Farm size distribution and land holding status}

Farmers have been categorized into three groups viz., small, medium, and large farmers. Farmers owning land upto 1 hectare have been considered as small farmers. Those who own land from 1-3 hectares have been considered as medium farmers and those owning above 3 hectares of land have been considered as large farmers. In the study area, the highest $50 \%$ of large farmers cultivate sugarcane as intercrop followed by medium (43\%) and small farmers $(07 \%)$. Likewise, highest proportion of large farmers cultivated sole sugarcane in this area. 
Therefore, large farmers were more interested to cultivate sugarcane as either sole or as intercrop sugarcane (Table0.

Table 1. Distribution of sample farmers according to the land holding/farm size.

\begin{tabular}{l|cc|c|c}
\hline \multirow{2}{*}{$\begin{array}{c}\text { Land holding } \\
\text { (ha) }\end{array}$} & \multicolumn{2}{|c|}{ Sole sugarcane } & \multicolumn{2}{c}{ Intercrop } \\
\cline { 2 - 5 } & Number & Percent & Number & Percent \\
\hline Up to 1 (Small) & 5 & 17 & 3 & 7 \\
1-3 (Medium) & 13 & 43 & 17 & 43 \\
Above 3 & 12 & 40 & 20 & 50 \\
\hline Total & 30 & 100 & 40 & 100 \\
\hline
\end{tabular}

Source: Field Survey, 2003.

\section{Per hectare yield, gross return, and net return}

Table 2 expressed per hectare gross return of sole sugarcane and intercrop. Per hectare yield of sole sugarcane was $70942 \mathrm{~kg}$ but per hectare yield of sugarcane in the intercropping system of sugarcane plus lentil, sugarcane plus maize, sugarcane plus potato, and sugarcane plus others were $74142 \mathrm{~kg}, 74412 \mathrm{~kg}$, $81875 \mathrm{~kg}$, and $74938 \mathrm{~kg}$, respectively. Per hectare yield of lentil, maize, potato, and others were $1080 \mathrm{~kg}, 3521 \mathrm{~kg}, 15858 \mathrm{~kg}$, and $5357 \mathrm{~kg}$, respectively. So, yield of sugarcane was higher in the intercropping system than the sole sugarcane system. The yield of sugarcane in the intercropping system increased due to additional management of sugarcane, such as intensive intercultural operation, application of fertilizer, and irrigation water. Highest sugarcane yield was found for sugarcane plus potato intercropping system. Per hectare total gross return of producing sole sugarcane was Tk. 84480 whereas per hectare total gross returns of sugarcane plus lentil, sugarcane plus maize, sugarcane plus potato, and sugarcane plus others intercropping system were Tk. 115373, Tk. 117198, Tk. 149192, and Tk. 158654, respectively. Per hectare net return were Tk. 4106, Tk. 20555, Tk. 22952, Tk. 30147, and Tk. 46877 in producing sole sugarcane, sugarcane plus lentil, sugarcane plus maize, sugarcane plus potato, and sugarcane plus others intercropping system, respectively (Table 3). This table also showed that the highest net return was obtained from sugarcane plus others (Tk. 46877) intercropping system followed by sugarcane plus potato (Tk. 30147) and sugarcane plus maize (Tk. 22952). Sole sugarcane gave the lowest net return (Tk. 4106). it is evident from Table 3 that the benefit cost ratios in full cost basis among sole sugarcane, sugarcane plus lentil, sugarcane plus maize, sugarcane plus potato, and sugarcane plus others intercropping system were 1.05, 1.22, $1.24,1.25$, and 1.42 , respectively. But in cash cot basis, benefit cost ratios were $1.74,2.13,1.91,1.88$, and 2.01, respectively. Therefore sugarcane plus others intercropping system is the best system in respect of full cost basis benefit cost ratio followed by sugarcane plus potato and sugarcane plus maize. But sugarcane plus lentil intercropping system is the best system in respect of cash cost basis benefit cost ratio followed by sugarcane plus others, sugarcane plus maize, and 
sole sugarcane system. In the above discussion, it is clear that farmers can get more profit from the same amount of land if they adopt intercropping system with sugarcane production. Thus cropping intensity can be increased, which will help in increasing total gross output of the country.

Table 2. Yield and gross return of sugarcane production as monoculture and as intercrop.

\begin{tabular}{|c|c|c|c|c|c|}
\hline \multirow[t]{2}{*}{ Practice } & \multicolumn{2}{|c|}{ Monoculture } & \multicolumn{2}{|c|}{ Intercropping } & \multirow[b]{2}{*}{ return } \\
\hline & Yield & $\begin{array}{l}\text { Gross } \\
\text { return }\end{array}$ & Yield & $\begin{array}{l}\text { Gross } \\
\text { return }\end{array}$ & \\
\hline Sole sugarcane & 70942 & 84480 & - & - & 84480 \\
\hline $\begin{array}{l}\text { Sugarcane } \\
\text { plus lentil }\end{array}$ & 74142 & 88317 & 1080 & 27057 & 115373 \\
\hline $\begin{array}{l}\text { Sugarcane } \\
\text { plus maize }\end{array}$ & 74412 & 88550 & 3521 & 28648 & 117198 \\
\hline $\begin{array}{l}\text { Sugarcane } \\
\text { plus potato }\end{array}$ & 81875 & 97233 & 15858 & 51959 & 149192 \\
\hline $\begin{array}{l}\text { Sugarcane } \\
\text { plus others }\end{array}$ & 74938 & 90143 & 5357 & 688511 & 158654 \\
\hline
\end{tabular}

Source: Field survey, 2003.

Land policy makers should think about the intercropping system, which will produce more amounts of food as well as net returns from the same amount land.

\section{Factors affecting profitability of sugarcane production as monoculture and as intercrop}

The factors which were significant for profitability of sugarcane production as monoculture are cost of family labour, cost of urea, cost of MP, time of set transplanting dummy, plant to plant distance, and number of fertilizing. The factors which were significant for profitability of sugarcane production as intercropping are cost of set, cost of labour, sowing/planting of intercrop.

\section{Cost of sett}

The regression coefficient of the variable cost of sett in monoculture was 0.27 , which is not significant indicating that cots of sett has no impact on profitability of sole sugarcane production. The coefficient of the variable was negative of 0.38 in the case of intercropping of sugarcane.

\section{Family labour}

The regression coefficient of family labour cost was negative (-0.19) in monoculture, which implied that $1 \%$ increase in family labour would decrease profit by $0.19 \%$ keeping other factors constant. The co-efficient was highly significant indicating that profit reduced significantly due to additional use of 
home supplied family labour. This situation is the indication of existence of disguised unemployment in our country.

\section{Cost of urea}

The regression coefficient of urea was negative $(-0.72)$ in monoculture which implied that $1 \%$ increase in the use of urea would decrease the profit by $0.72 \%$ holding other factors constant. This co-efficient was highly significant indicating that profit reduced significantly due to excessive use of urea increased the production cost causing decline in the profit. The coefficient was negative in intercropping practice (Table 5).

The estimated co-efficient was insignificant, indicating that cost of urea insignificantly influence the profit of sugarcane intercropping due to excessive use of urea increased the cost of production causing a decline in the profit.

\section{Cost of MP}

The regression coefficient of MP was positive (0.21) in monoculture and it was significant at $5 \%$ level of significance. It indicated that $1 \%$ increase in the use of MP would increase the profit by $0.21 \%$ keeping other factors constant.

\section{Time of sett transplantation dummy}

The estimated coefficient of time of sett transplantation dummy was negative (0.09) and significant in monoculture, but it was insignificant in intercropping. Generally sett transplanting has an optimum period, the violation of this specific period reduce production, causing a decline in the profit.

\section{Plant to plant distance}

The estimated coefficient of plant to plant distance was negative (-0.08) and significant in monoculture. If plant to plant distance increased the total production decreased and ultimately the profit declined. So an optimum distance should be maintained between the plants of sugarcane for obtaining the higher level of production and profit. 


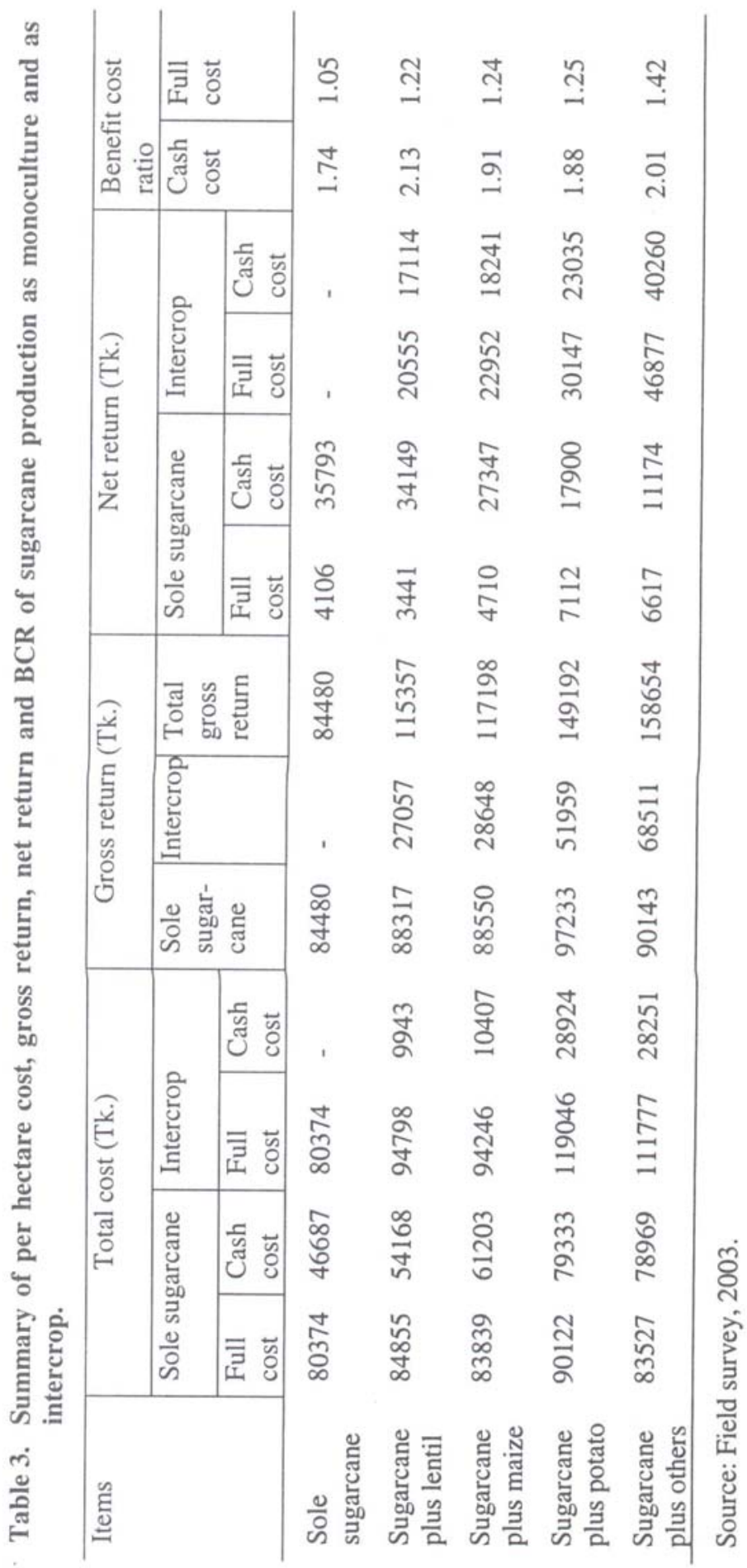




\section{Number of fertilizing}

The estimated coefficient of the variable was positive (0.39) and significant at $1 \%$ level of significance in monoculture. Due to increase in the number of fertilizing increased production causing a rise in the profit.

The coefficient of multiple determination $\left(\mathrm{R}^{2}\right)$ was 0.97 , which indicated that all the explanatory variables explained $97 \%$ variation of profit. The F-values was significant at $1 \%$ level of significance indicating that the regression fitted well.

Table 4. Estimated value of coefficient and related statistics of Cobb-Douglas production function of sole sugarcane production.

\begin{tabular}{lcc}
\hline Variable & Coefficient & T-ratio \\
\hline Constant & 11.32 & 5.105 \\
Cost of Setts $\left(\mathrm{X}_{1}\right)$ & 0.27 & 1.586 \\
Cost of hired labor $\left(\mathrm{X}_{2}\right)$ & -0.19 & -0.885 \\
Cost of family labour $\left(\mathrm{X}_{3}\right)$ & -0.19 & -3.459 \\
Cost of urea $\left(\mathrm{X}_{4}\right)$ & -0.73 & -3.424 \\
Cost of TSP $\left(\mathrm{X}_{5}\right)$ & -0.02 & -0.294 \\
Cost of MP $\left(\mathrm{X}_{6}\right)$ & 0.21 & 2.487 \\
Cost of insecticides $\left(\mathrm{X}_{7}\right)$ & 0.01 & 0.167 \\
Cost of irrigation $\left(\mathrm{X}_{8}\right)$ & 0.02 & 0.158 \\
Time of sett transplanting dummy $\left(\mathrm{X}_{9}\right)$ & -0.09 & -2.068 \\
Row to row distance, cm $\left(\mathrm{X}_{10}\right)$ & 0.01 & 1.675 \\
Plant to plant distance, cm $\left(\mathrm{X}_{11}\right)$ & -0.08 & -5.589 \\
Number of fertilizing $\left(\mathrm{X}_{12}\right)$ & 0.39 & 4.744 \\
Number of weeding $\left(\mathrm{X}_{13}\right)$ & -0.04 & -0.620 \\
Rent of land $\left(\mathrm{X}_{14}\right)$ & 0.35 & 1.701 \\
$\mathrm{R}^{2}$ & 0.97 & - \\
adjusted $\mathrm{R}^{2}$ & 0.86 & - \\
$\mathrm{F}$ & $9.05^{*}$ & - \\
\hline
\end{tabular}

Note: $* 1 \%$ level of significance, $* * 5 \%$ level of significance.

\section{Cost of labour}

The regression coefficient of cost of labour was positive (0.68) and significant at $1 \%$ level of significance in intercropping, which implied that $1 \%$ increase in the cost of total labour would increase the profit by $0.68 \%$, keeping the other factors constant. Increasing use of labour would increase production causing a rise in the profit.

\section{Sowing/planting of intercrop}

The regression coefficient of sowing of intercrop was negative (-0.22) and highly significant. The estimated significant coefficient indicated that sowing/planting of intercrop significantly influences the profit of sugarcane production. 
The coefficient of multiple determinations $\mathrm{R}^{2}$ was 0.558 , which indicated that $56 \%$ variation in profit was explained by all of the explanatory variables. The Fvalue was 4.412 and was significant at $5 \%$ level of significance, indicating that the regression fitted well.

Table 5. Estimated value of coefficient and related statistics of Cobb-Douglas production function of intercrop sugarcane production.

\begin{tabular}{l|l|l}
\hline Variable & Coefficient & T-ratio \\
\hline Constant & $9.99^{* *}$ & 2.271 \\
Cost of setts $\left(\mathrm{X}_{1}\right)$ & $-0.38^{*}$ & -3.116 \\
Cost of seeds $\left(\mathrm{X}_{2}\right)$ & 0.02 & 0.524 \\
Cost of total labour $\left(\mathrm{X}_{3}\right)$ & $0.68^{*}$ & 2.924 \\
Cost of urea $\left(\mathrm{X}_{4}\right)$ & -0.27 & -1.776 \\
Cost of insecticides $\left(\mathrm{X}_{5}\right)$ & 0.08 & 0.955 \\
Cost of irrigaition $\left(\mathrm{X}_{6}\right)$ & -0.17 & -1.508 \\
Ploughing cost $\left(\mathrm{X}_{7}\right)$ & 0.09 & 0.466 \\
Rent of land $\left(\mathrm{X}_{8}\right)$ & -0.14 & -0.519 \\
Time of sett transplanting dummy $\left(\mathrm{X}_{9}\right)$ & 0.05 & 0.605 \\
Sowing/planting of intercrop $\left(\mathrm{X}_{10}\right)$ & $-0.22^{*}$ & -3.153 \\
Row to row distance $\left(\mathrm{X}_{11}\right)$ & 0.20 & 1.020 \\
Plant to plant distance, cm $\left(\mathrm{X}_{12}\right)$ & 0.16 & 0.489 \\
$\mathrm{R}^{2}$ & 0.558 & - \\
Adjusted $\mathrm{R}^{2}$ & 0.431 & - \\
$\mathrm{F}$ & $4.412^{* *}$ & - \\
\hline Note: & &
\end{tabular}

Note: $* 1 \%$ level ofsignificance, $* * 5 \%$ level of significance.

\section{Problems and constraints of sugarcane and its intercrop production}

There were many problems and constraints in producing sugarcane as monoculture and as intercrop. Three categories of problems and constraints, such as economic, technical, and social problems have been identified in the study area.

Economic problems and constraints which are related to the financial difficulties are lack of capital, high price of input, low price of output, etc. All farmers reported that high prices of inputs is an acute problem in the way of practicing sugarcane and its intercrop production (Table 6). High interest rate is another major problem for both categories of growers in the study area. Lack of capital is also an important problem for sole and intercrop sugarcane growers. Low price of output and lack of transportation system is also important problem for sole sugarcane growers than intercrop growers. Technical constraints are related to production techniques and technologies, such as lack of scientific knowledge, setts/seeds, pesticides and insecticides, store facilities, inadequate irrigation facilities, and natural calamities, etc. 
Social problems are related to theft of sugarcane, top cutting, and dishonesty of officials. All sample farmers reported that dishonesty of officials was another acute problem for both sugarcane growers. Most of the farmers reported that the villagers were habituated to cut the top of sugarcane for using it as cattle feed. This is the second most problem for both growers. Sugarcane is an attractive and testy corp. People, especially children are generally attracted to it. Chewing of cane was third social problems reported by sugarcane growers in the study area.

Table 6. Distribution of constraints and problems of sugarcane production as monoculture and as intercropping.

\begin{tabular}{|c|c|c|c|c|}
\hline \multirow[t]{2}{*}{ Name of the problem } & \multicolumn{2}{|c|}{ Monoculture sugarcane } & \multicolumn{2}{|c|}{ Intercrop sugarcane } \\
\hline & Value $^{1}$ & Rank & Value $^{1}$ & Rank \\
\hline \multicolumn{5}{|c|}{ Economic problem } \\
\hline Lack of capital & 7 & 2 & 6 & 3 \\
\hline Low price of output & 3 & 3 & 4 & 4 \\
\hline $\begin{array}{l}\text { Lack of transportation } \\
\text { system }\end{array}$ & 2 & 4 & 3 & 5 \\
\hline High price of input & 10 & 1 & 10 & 1 \\
\hline High interest rate & 7 & 2 & 7 & 2 \\
\hline \multicolumn{5}{|c|}{ Technical problem } \\
\hline $\begin{array}{l}\text { Lack of scientific } \\
\text { knowledge }\end{array}$ & 7 & 1 & 8 & 1 \\
\hline $\begin{array}{l}\text { Lack of good quality } \\
\text { set/sapling and intercrop } \\
\text { seed }\end{array}$ & 6 & 2 & 6 & 2 \\
\hline $\begin{array}{l}\text { Problems of insecticides } \\
\text { and pesticides use }\end{array}$ & 2 & 4 & 2 & 4 \\
\hline Lack of storage facilities & 0 & - & 1 & 5 \\
\hline Natural calamities & 4 & 3 & 5 & 3 \\
\hline \multicolumn{5}{|c|}{ Social problem } \\
\hline Theft ofsugarcane & 3 & 3 & 3 & 3 \\
\hline Theft of tob of sugarcane & 4 & 2 & 6 & 2 \\
\hline Dishonesty of officials & 10 & 1 & 10 & 1 \\
\hline
\end{tabular}

Source: Field Survey, 2003.

1 Values were assigned from 1 to 10,10 indicated the highest value and ranked 1 , while 1 is lowest value ranked 10.

\section{Reasons of sole and intercrop sugarcane cultivation}

Intercropping of winter crops with sugarcane is very popular and profitable. Cane growers raise crops like lentil, maize, potato, etc. between the two rows of sugarcane as intercrops. To introduce intercrops, there are many reasons. In the study area, $40 \%$ farmers reported that it gives additional income for both type of sugarcane cultivation (Table 7). Thirty percent of sole sugarcane farmers reported that sugarcane cultivation was more profitable, but $32 \%$ of intercrop 
producers told that with intercrop, sugarcane cultivation was more profitable. Some of the farmers raised sugarcane cultivation for own consumption and some of them cultivate sugarcane for proper use of land.

Table 7. Distribution of reasons of sole and intercrop sugarcane cultivation.

\begin{tabular}{lccc}
\hline \multicolumn{3}{c}{ Reasons behind sugarcane cultivation as sole } \\
\hline Reasons & Number & Percent \\
\hline Profitability & 9 & 30 \\
Additional income & 12 & 40 \\
Ensure the proper use of land & 6 & 20 \\
For consumption & 3 & 10 \\
\hline \multicolumn{3}{c}{ Reasons behind intercropping sugarcane cultivation } \\
\hline Reasons & Number & Percent \\
\hline Profitability & 13 & 32 \\
Additional income & 16 & 40 \\
Ensure the proper use of land & 7 & 18 \\
For consumption & 4 & 10 \\
\hline
\end{tabular}

Source: Field Survey, 2003.

\section{Conclusion}

The study reveals that the sugarcane plus potato combination produced the highest net return followed by sugarcane plus maize, sugarcane plus lentil, and sole sugarcane. The highest returns yielded by the sugarcane plus potato intercrop system were supported by previous studies (Kabir, 1988; Miah, 1992). Cost of family labour, cost of urea, cost of MP, time of sett transplanting, plant to plant distance were factors which significantly affected profitability of sugarcane as monculture. Cost of total labour, cost of setts, sowing/planting of intercrops were the factors which significantly affecting profitability of sugarcane production as intercrop. Some farmers are interested to increase their intercropped areas to earn maximum profit but they are not able to practice it in a large scale due to some problems and constraints. The major problems were high price of inputs, lack of scientific knowledge, and dishonesty of officials. Therefore, in order to promote intercropping in a large scale with sugarcane, government and non-government organizations must encourage farmers to produce sugarcane as intercrop. This will enable the farmers to earn the highest net returns.

\section{References}

BBS. 2002. Year Book of Agricultural Statistics of Bangladesh. Statistical Division, Bangladesh bureau of Statistics. Ministry of Planning, Govt. of the People's Republic of Bangladesh. 
Chujaemi. M., S, Arifin, Surachman, Mudefar. 1998. Intercropping of sugarcane and soyabeans in West Rayon Ketanggungan, Tersana Baru sugar manufacture, Indonesia. Berita Pusat Penelitioan Perkebunan Gula Indonesia 22: 17-19.

Gana, A.K., L.D. Busari. 1999. Yield and returns of sugarcane (Saccharum officinarum) intercropping with horticultural crops. National Cereals Research Institute, Badeggi, P.M.B. 8, Niger State, Nigeria. Agricultura Tropica et Subtropica 32: 59-64.

Gangwar. K.S. and S. K. Sharma. 1997. Simultaneous planning of sugarcane (Saccharum officinarum) and wheat (Triticum aestivum) for higher productivity and profitability of sugarcane-wheat system. Indian Journal of Agronomy 42(4): 657-660.

Imran.M., A. Shaukat, M. Ilyas, A. ishtiaq, I. Muhammad, S. Ayaz, I. Mahmood and I. Ahmad. 2000. A glance at the agro-economic study of sugar intercropping with three other crop. Pakistan Sugar Journal 15(1): 18-21.

Kabir, M. H. 1988. Economics of intercropping with sugarcane in selected areas of north Bengal Sugar Mills Zone. Bangladesh Journal of Sugarcane 10: 81-86.

Miah, M. A. M. 1992. An economic study on sugarcane cultivation with several intercriops in Joypurhat Sugarmills areas. An unpublished M. Sc. Thesis. Dept. of Agril. Economics, BAU, Mymensingh.

Muhammad. A., M. A. Javed, K.B. Malik and M. Aslam. 1998. Economic feasibility of intercropping raya and sunflower at different plant densities in autumn planted sugarcane. Pakistan Sugar Journal 13(2): 15-17.

Sarjit, S., S. Makhan, M.L. Kapoor, A.I.S. Garcha, L.K. Saini, S. Singh, and M. Singh. 1999. Productivity and economics of autumn sugarcane-based intercropping stystes. Indian Sugar 48: 977-981.

Shankaraiah, C., S.R. Vishwantha, M.S. Nagaraju, P. Rudraswamy. 1999. Soybean varietal interaction under sugarcane plus soybean intercropping system. Mysore Journal of Agricultural Sciences 33(4): 306-311.

Singh. R.K. and R. K. Chauhan. 1998. Effect of intercropping on yield and quality of sugarcane. Agricultural Science Digest Karnal 18(4): 255-257.

Zohry. A.H. A. 1999. Effect of intercropping onion with autumn planted sugar cane on cane yield and juice quality. Egyptian Journal of Agricultural Research 77(1): 273287. 